\title{
Reversing the defective induction of IL-10-secreting regulatory $T$ cells in glucocorticoid-resistant asthma patients
}

\author{
Emmanuel Xystrakis, ${ }^{1}$ Siddharth Kusumakar, ${ }^{1}$ Sandra Boswell, ${ }^{1}$ Emma Peek, ${ }^{1}$ \\ Zoë Urry, ${ }^{1}$ David F. Richards, ${ }^{1}$ Tonye Adikibi, ${ }^{1}$ Carol Pridgeon, ${ }^{2}$ Margaret Dallman, ${ }^{2}$ \\ Tuck-Kay Loke, ${ }^{1}$ Douglas S. Robinson,, ${ }^{2,3}$ Franck J. Barrat, ${ }^{4}$ Anne O'Garra, ${ }^{5}$ \\ Paul Lavender, ${ }^{1}$ Tak H. Lee, ${ }^{1}$ Christopher Corrigan, ${ }^{1}$ and Catherine M. Hawrylowicz ${ }^{1}$
}

\begin{abstract}
${ }^{1}$ Medical Research Council and Asthma-UK Centre in Allergic Mechanisms of Asthma at King's College London, Strand, London, United Kingdom. ${ }^{2}$ Life Sciences and ${ }^{3}$ Medical Research Council and Asthma-UK Centre in Allergic Mechanisms of Asthma at Imperial College, Imperial College, London, United Kingdom. ${ }^{4}$ Dynavax Technologies Corp., Berkeley, California, USA. ${ }^{5}$ Laboratory of Immunoregulation, National Institute for Medical Research, Mill Hill, London, United Kingdom.
\end{abstract}

\begin{abstract}
We previously reported that human $\mathrm{CD}^{+}$Tregs secrete high levels of IL-10 when stimulated in the presence of dexamethasone and calcitriol (vitamin D3). We now show that following stimulation by allergen, IL-10-secreting Tregs inhibit cytokine secretion by allergen-specific Th2 cells in an IL-10-dependent manner. A proportion of patients with severe asthma fail to demonstrate clinical improvement upon glucocorticoid therapy, and their asthma is characterized as glucocorticoid resistant (SR, abbreviation derived from "steroid resistant"). Dexamethasone does not enhance secretion of IL-10 by their $\mathrm{CD}^{+} \mathrm{T}$ cells. Addition of vitamin $\mathrm{D} 3$ with dexamethasone to cultures of SR CD4 ${ }^{+} \mathrm{T}$ cells enhanced IL-10 synthesis to levels observed in cells from glucocorticoid-sensitive patients cultured with dexamethasone alone. Furthermore, pretreatment with IL-10 fully restored IL-10 synthesis in these cells in response to dexamethasone. Vitamin D3 significantly overcame the inhibition of glucocorticoid-receptor expression by dexamethasone while IL-10 upregulated glucocorticoid-receptor expression by $\mathrm{CD}^{+} \mathrm{T}$ cells, suggesting potential mechanisms whereby these treatments may overcome poor glucocorticoid responsiveness. We show here that administration of vitamin D3 to healthy individuals and SR asthmatic patients enhanced subsequent responsiveness to dexamethasone for induction of IL-10. This strongly suggests that vitamin D3 could potentially increase the therapeutic response to glucocorticoids in SR patients.
\end{abstract}

\section{Introduction}

$\mathrm{CD}^{+} \mathrm{Th} 2$ cells are implicated in the pathogenesis of asthma and allergic diseases through the actions of IL-4 and IL-13, which switch B cells to IgE synthesis; IL-5, which plays a role in eosinophil maturation and survival; and IL-13, which regulates airway hyperresponsiveness and mucus hyperplasia (1). Glucocorticoids are the first-line antiinflammatory treatment for asthma (2). Their multiple inhibitory properties, including the inhibition of Th2 cytokine synthesis, are likely to contribute to clinical efficacy. Glucocorticoids also enhance $\mathrm{IL}-10$ production in vitro by human $\mathrm{CD} 4^{+}$and $\mathrm{CD} 8^{+} \mathrm{T}$ cells (3), and glucocorticoid treatment induces the synthesis of IL-10 by airway cells in asthmatic patients (4). IL-10 is a potent antiinflammatory and immunosuppressive cytokine that mediates its major immunosuppressive function by inhibiting APC function and cytokine production by macrophages and dendritic cells, leading to profound inhibition of Th1 cell-mediated immunity (5). IL-10 also regulates effector responses associated with established allergic and asthmatic disease, including inhibition of cytokine production by Th2 cells as well as mast cell and eosinophil function and modulation of IgG4:IgE ratios $(5,6)$. There appears to be an inverse correlation between IL-10 levels and the incidence and/or severity of asthmatic

Nonstandard abbreviations used: $\mathrm{FEV}_{1}$, forced expired volume in 1 second; GR, glucocorticoid receptor; SR, glucocorticoid resistant; SS, glucocorticoid sensitive.

Conflict of interest: The authors have declared that no conflict of interest exists.

Citation for this article: J. Clin. Invest. 116:146-155 (2006)

doi:10.1172/JCI21759. and allergic disease (7-10). Furthermore, studies in animal models of transfer of the IL-10 gene directly to the lung (11) or adoptive transfer of IL-10 transfected CD4+ $\mathrm{T}$ cells (12) demonstrate that IL-10 can block allergic airway inflammation (reviewed in ref. 6). These studies imply a central role for IL-10 in disease control and suggest that the induction of IL-10 synthesis may contribute to the clinical efficacy of glucocorticoids in allergy and asthma.

A proportion of asthmatic patients fails to benefit from oral glucocorticoid therapy and are thus denoted as having glucocorticoid-resistant (SR, derived from "steroid resistant") or insensitive asthma (13). SR is associated with in vitro and in vivo alterations in cellular responses to exogenous glucocorticoids. We have previously demonstrated that $\mathrm{CD} 4^{+} \mathrm{T}$ cells from SR asthma patients fail to induce IL-10 synthesis following in vitro stimulation in the presence of dexamethasone as compared with their glucocorticoid-sensitive counterparts (SS, derived from "steroid sensitive") (14), suggesting a link between induction of IL-10 synthesis and clinical efficacy of glucocorticoids. Resistance to the inhibitory effects of glucocorticoids can be induced in $\mathrm{T}$ cells in vitro, for example, by incubation with IL-2 and IL-4 (15). It may, therefore, be possible to modulate the function of SR $\mathrm{CD} 4^{+} \mathrm{T}$ cells in vitro and restore IL-10 synthesis.

One potential source of IL-10 is Tregs, which control the function of effector $\mathrm{T}$ cells, thereby preventing responsiveness to self antigens and regulating immune responses. The major Treg populations described to date include naturally occurring $\mathrm{CD} 4{ }^{+} \mathrm{CD} 25^{+}$ Tregs and inducible IL-10 or TGF- $\beta$ secreting Tregs (16-18). 

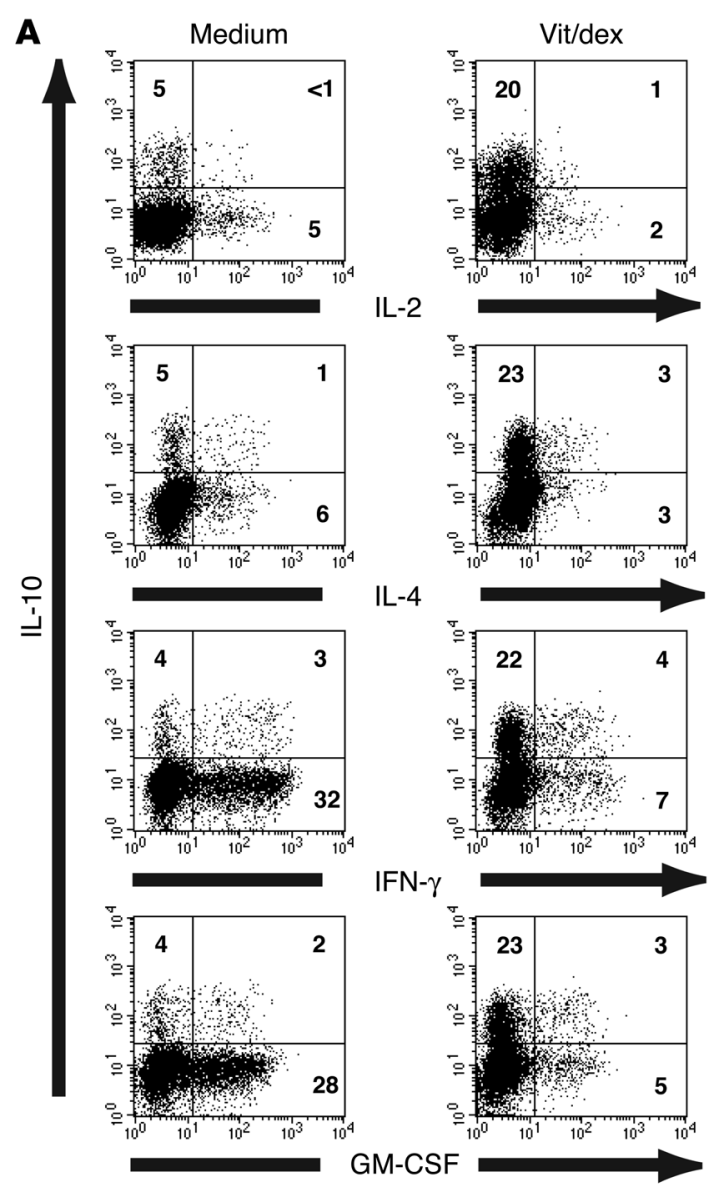

B
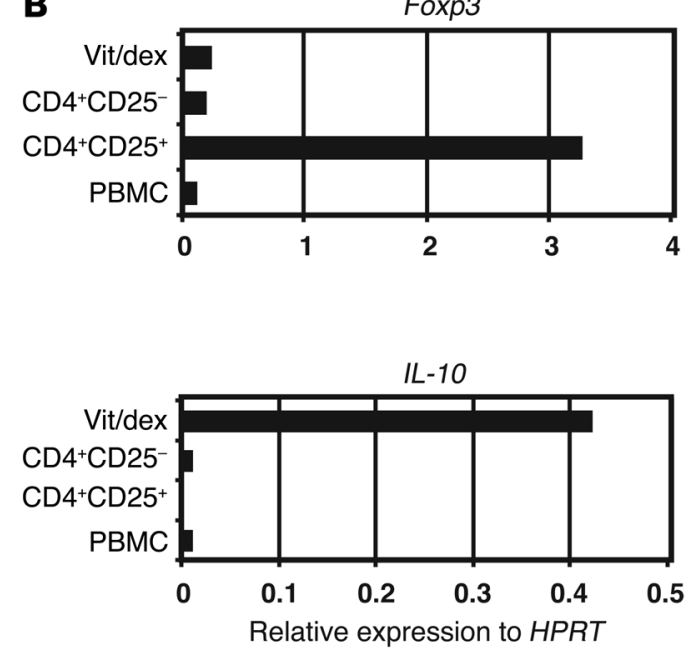

Figure 1

Polyclonal activation of human CD4+ T cells in the presence of dexamethasone plus vitamin D3 induces IL-10 expression, which does not correlate with expression of the transcription factor Foxp3. (A) CD4+ $4^{+}$cells from an SS asthma patient were cultured with APCs, anti-CD3, IL-2, and IL-4 alone (medium) or together with $10^{-7} \mathrm{M}$ Vitamin D3 and $10^{-7} \mathrm{M}$ dexamethasone (vit/dex). Cells were restimulated at 7 days with PMA and ionomycin for 4 hours, and coexpression of IL-10 with IL-2, IL-4, IFN- $\gamma$, or GM-CSF was analyzed by flow cytometry. Data are representative of 5 experiments. (B) Real-time RT-PCR was performed on PBMCs, freshly isolated CD4+CD25- and CD4+CD25+ $4^{+}$cells, and IL-10-secreting Tregs harvested after 14 days in culture to compare expression of Foxp3 and IL-10. Data are representative of 3 experiments. HPRT, hypoxanthine-guanine phosphoribosyl transferase.

IL-10-secreting Tregs have been described following different regimens of antigenic administration both in vitro and in vivo (19-24). Our initial studies showed that glucocorticoids enhanced the production of IL-10 by polyclonally stimulated T cells and that these cells inhibited IFN- $\gamma$ production by human $\mathrm{CD}^{+} \mathrm{T}$ cells in an IL-10-dependent manner (3). More recently, we demonstrated in both mouse and human that a combination of dexamethasone and calcitriol, the active form of vitamin D3, induced high numbers of IL-10-producing T cells that made negligible amounts of Th1 and Th 2 cytokines (25). The inhibitory activity of these cells was demonstrated in vivo, where adoptive transfer of IL-10secreting Tregs inhibited the development of murine experimental allergic encephalomyelitis (25); and in vitro, where they inhibited the proliferation of naive T cells (26). However, no data are yet available on the capacity of drug-induced IL-10-secreting Tregs to inhibit previously activated T cells, specifically Th 2 cells, a major therapeutic target in allergic asthma. In vitro suppression by $\mathrm{CD} 4^{+} \mathrm{CD} 25^{+} \mathrm{T}$ cells appears to be independent of IL-10 (27) whereas in vivo regulation by these cells is IL-10 dependent in some models (28-30). The transcription factor Foxp3 has recently been reported to be specifically expressed by $\mathrm{CD} 4{ }^{+} \mathrm{CD} 25^{+}$Tregs, controlling their development and function (31). To date, the relationship between naturally occurring $\mathrm{CD} 4{ }^{+} \mathrm{CD} 25^{+}$Tregs and IL-10-secreting Treg subsets is unclear.

In this study, we describe the in vitro inhibitory potential of human IL-10-secreting Tregs, derived by stimulation in the presence of vitamin D3 and dexamethasone, to inhibit cytokine production by allergen-specific Th2 cells associated with immune pathology in allergic asthma. We further demonstrate that impaired induction of IL-10 by glucocorticoids in T cells from SR patients can be reversed by vitamin D3 and IL-10, leading to levels of IL-10 production comparable to those observed in SS asthmatic patients, and examine the mechanisms by which this may occur.

\section{Results}

Short-term culture of $C D 4^{+} T$ cells with glucocorticoids plus vitamin D3 is sufficient to generate IL-10-secreting Tregs. One week of culture of $\mathrm{CD} 4^{+} \mathrm{T}$ cells with anti-CD3, APCs, IL-2, and IL-4 in the pres- 

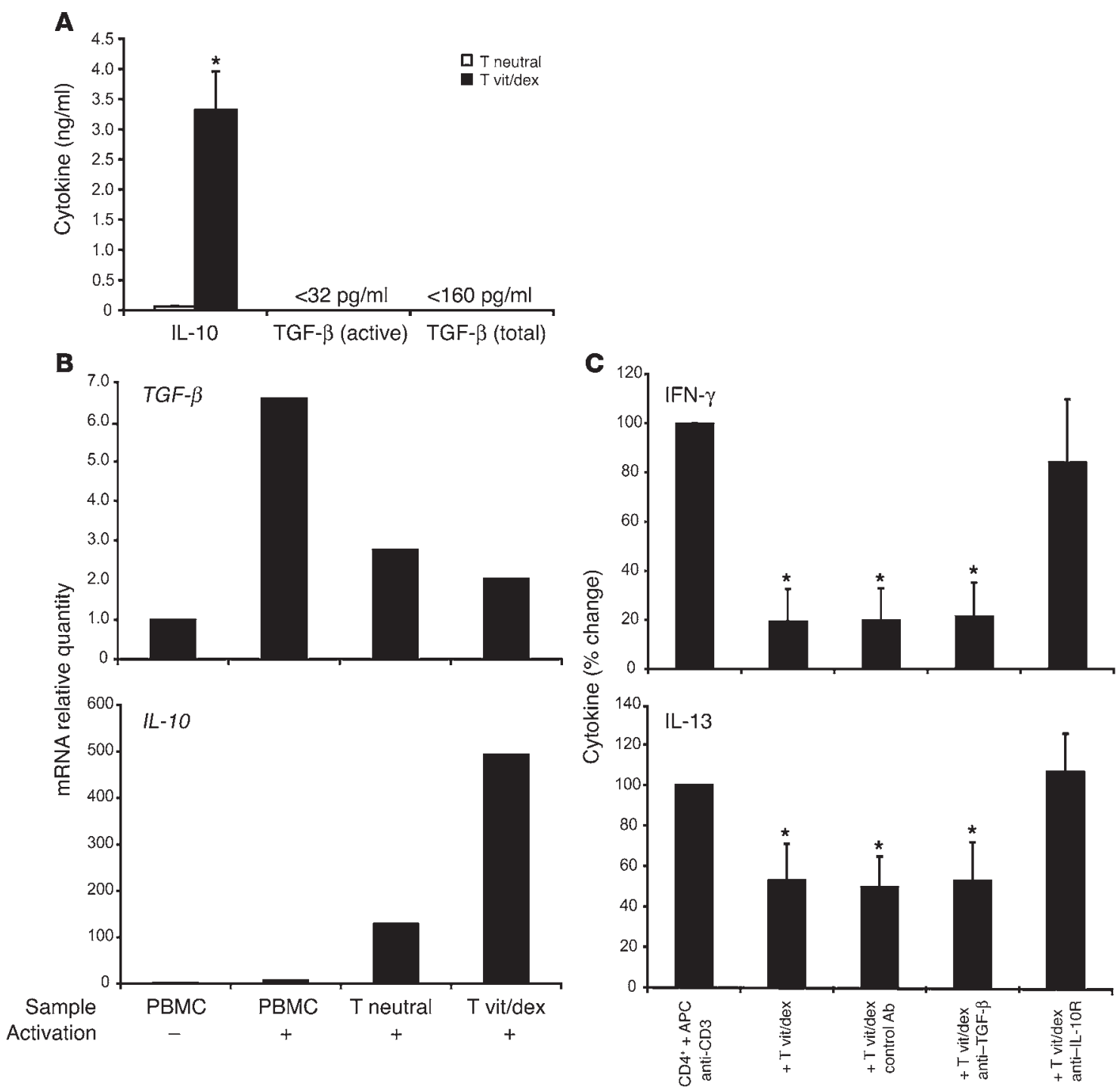

Figure 2

TGF- $\beta$ is not upregulated by vitamin D3 and dexamethasone treatment and does not play a role in IL-10-secreting Treg-mediated suppression of Th1 and Th2 cytokine production. (A) CD4+ $T$ cells were stimulated for 7 days with (T vit/dex) or without (T neutral) vitamin D3 and dexamethasone, as for Figure 1, and restimulated without drugs for 48 hours. TGF- $\beta$ and IL-10 levels in culture supernatants were determined by ELISA. Mean data of 3 experiments are shown. (B) CD4 ${ }^{+} \mathrm{T}$ cells were cultured for two 7-day cycles with or without vitamin D3 and dexamethasone and then activated with PMA and ionomycin for 4 hours. PBMCs were cultured without or with PMA and ionomycin for 4 hours. TGF- $\beta$ and $I L-10$ mRNA were determined by real-time RT-PCR and expressed relative to unactivated PBMCs. A representative experiment of 4 is shown. (C) CD4+ $\mathrm{T}$ cell lines were cultured for 7 days with vitamin D3 and dexamethasone and then used in cocultures with fresh autologous T cells (1:4 ratio) and irradiated APCs. Day 3 supernatants were assessed for IFN- $\gamma$ and IL-13 content. Mean data from 4 experiments is shown. ${ }^{*} P<0.05$ using 2-tailed Student's $t$ test.

ence of dexamethasone and vitamin D3 promoted an IL-10expressing phenotype and a reduction in Th1- and Th2-associated cytokines as well as GM-CSF, a key cytokine implicated in allergic airway inflammation (32) (6\% IL-10-positive T cells in medium versus $26 \%$ IL-10-positive T cells in the presence of vitamin D3 plus dexamethasone; Figure 1A). In the absence of IL-4, T cells stimulated in the presence of vitamin D3 and dexamethasone showed reduced cell survival (data not shown) but still demonstrated enhanced IL-10 synthesis (4\% IL-10-positive $\mathrm{T}$ cells in medium versus $15 \% \mathrm{IL}-10$-positive $\mathrm{T}$ cells in presence of vitamin D3 plus dexamethasone).
IL-10-secreting Tregs express low levels of Foxp3 and are distinct from Th3 regulatory cells. To determine a possible relationship between naturally occurring $\mathrm{CD} 4{ }^{+} \mathrm{CD} 25^{+}$Tregs and antigen-stimulated IL-10-secreting Tregs, we compared the expression of the transcription factor Foxp3 and $I L-10$ using real-time PCR analysis. In vitro-derived IL-10-secreting Tregs harvested at the end of 14 days of culture expressed comparatively low amounts of Foxp3 mRNA compared with unstimulated $\mathrm{CD} 4^{+} \mathrm{CD} 25^{+}$Tregs isolated directly ex vivo (Figure 1B). In contrast, IL-10-secreting Tregs expressed markedly higher amounts of mRNA encoding $\mathrm{IL}-10$ than $\mathrm{CD} 4^{+} \mathrm{CD} 25^{+}$ Tregs, suggesting that these 2 regulatory populations may repre- 


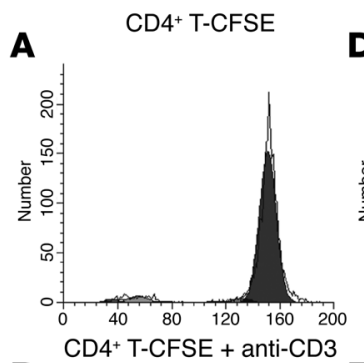

B

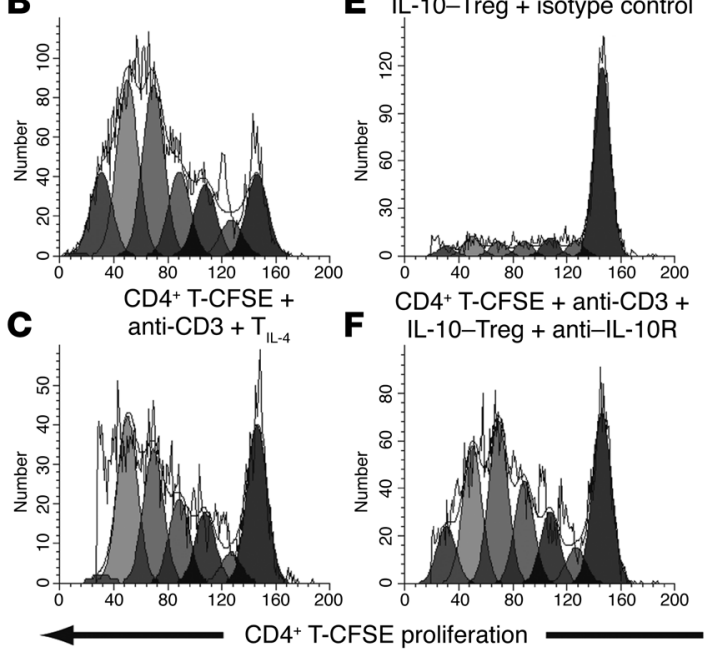

CD4+ T-CFSE +
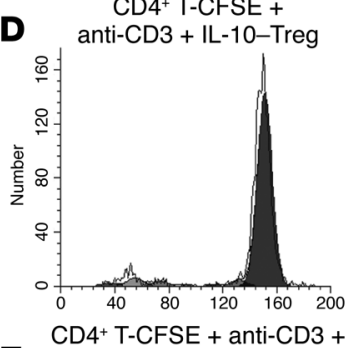

E IL-10-Treg + isotype control
G

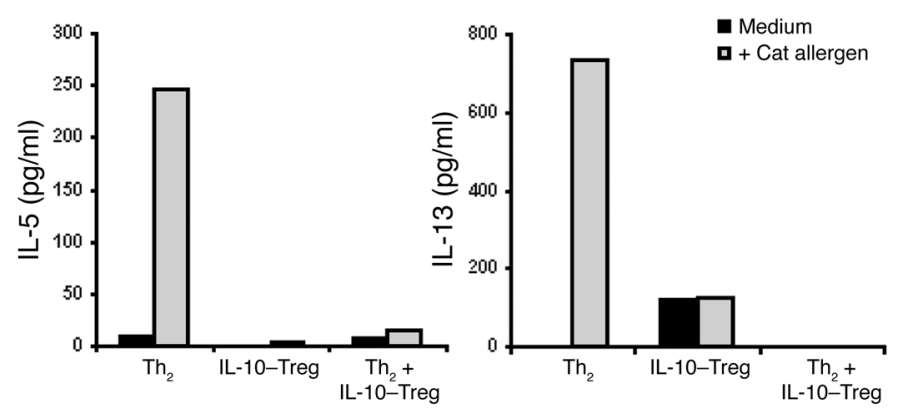

$\mathbf{H}$

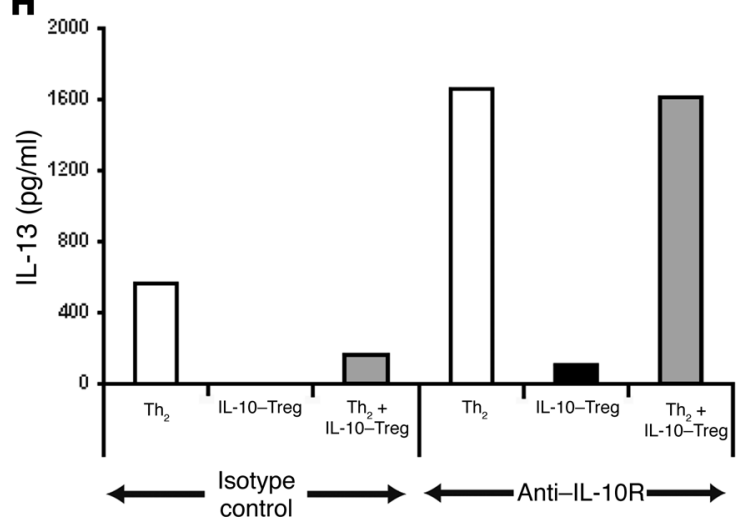

Figure 3

IL-10-secreting Tregs inhibit polyclonal T cell proliferative responses to anti-CD3 and cytokine production by allergen-stimulated Th2 cells. This inhibition is reversed by an IL-10 antagonist. (A-F). Freshly isolated CFSE-labeled CD4+ T cells (CD4+ T-CFSE) were cultured with irradiated APCs and (A) medium or (B) anti-CD3. Alternatively, they were (C) cocultured at a ratio of $1 \mathrm{~T}_{\mathrm{IL}-4}$ to 4 CD4+ T-CFSE or (D-F) 1 IL-10-secreting Treg (IL-10-Treg) to 4 CD4+ T-CFSE. (E) Isotype control or (F) anti-IL-10 receptor monoclonal antibodies were added as indicated. Cell-cycle progression was analyzed at day 6. (G) Allergen-specific IL-10-secreting Tregs or Th2 cells were cultured alone or together (1 IL-10-secreting Treg to 4 Th2 cells) with APCs in medium or with cat allergen extract. Day 3 culture supernatants were analyzed by ELISA and cytometric bead array. Data are representative of 5 experiments. $(\mathbf{H})$ Grass pollen allergen extract-stimulated cultures were established as above with the addition of a control isotype or anti-IL-10 receptor monoclonal antibody as indicated. Cytokine levels detected in the absence of allergen were $200 \mathrm{pg} / \mathrm{ml}$ or less and were subtracted in all groups. Data are representative of 3 experiments.

sent 2 distinct lineages (Figure 1B). Similarly, to permit a comparison of drug-induced IL-10-secreting Tregs with TGF- $\beta$-secreting Th3 cells, $\mathrm{CD}^{+} \mathrm{T}$ cells were cultured in the presence or absence of vitamin D3 and dexamethasone in serum-free media to facilitate analysis of TGF- $\beta$ secretion. The drug treatment enhanced IL-10 production, as assessed by both ELISA and quantitative PCR analysis, but no increase in TGF- $\beta$ was observed in the same cultures, suggesting drug-induced IL-10-secreting Tregs are distinct from Th3-type regulatory cells (Figure 2, A and B).

Human IL-10-secreting Tregs inhibit the proliferation of autologous $T$ cells in an IL-10-dependent manner. To determine whether druginduced IL-10-secreting Tregs manifest regulatory function for inhibition of $\mathrm{CD} 4^{+} \mathrm{T}$ cell proliferation, autologous $\mathrm{CD} 4^{+} \mathrm{T}$ cells were isolated and labeled with the fluorescent dye CFSE. Cell cycle progression of CFSE-labeled $\mathrm{CD}^{+} \mathrm{T}$ cells was analyzed on day 6 by flow cytometry after stimulation with anti-CD3 and APCs (Figure 3B; the ModFit-generated proliferation index of CFSE $\mathrm{CD}^{+} \mathrm{T}$ cells in the absence or presence of anti-CD3 was 1.1 versus 5.95). IL-10-secreting Tregs blocked the cell cycle progression of the freshly isolated $\mathrm{CD} 4^{+} \mathrm{T}$ cells at a ratio of $1 \mathrm{IL}-10-$ secreting Treg to 4 CFSE CD4 ${ }^{+} \mathrm{T}$ cells (Figure 3D; proliferation index, 1.55). This inhibition of proliferation by IL-10-secreting Tregs was reversed by the addition of anti-IL-10R mAbs (Figure 3F; proliferation index, 5.12), in contrast to an isotype control, which showed little effect (Figure 3E; proliferation index, 2.03). As few as $1 \mathrm{IL}-10$-secreting Treg could ablate the proliferative response of 16 CFSE-labeled responder T cells (data not shown). T cell lines generated with IL-4 in the absence of drugs had little or no effect on cell cycle progression of the autologous freshly derived CFSE$\mathrm{CD}^{+} \mathrm{T}$ cells (Figure 3C; proliferation index, 5.3).

IL-10-secreting Tregs inhibit cytokine synthesis from allergen-specific Th2 cell lines. Allergen-specific Th 2 cells and IL-10-secreting Tregs were generated in parallel cultures using $\mathrm{T}$ cells from the same atopic donor. After two 7-day cycles of stimulation with cat allergen presented by autologous, irradiated T cell-depleted PBMC, the cells were stimulated alone or together at a ratio of 1 IL-10-secreting Treg to 4 Th2 cells with APCs and with or without allergen. IL-10secreting Tregs inhibited IL-5 and IL-13 synthesis by allergenstimulated Th2 cells almost to the levels of cytokine production detected in supernatants of unstimulated Th2 cells (Figure 3G). As predicted from independent studies demonstrating IL-10 synthesis by Th 2 cells, addition of anti-IL-10R mAbs to cultures of cat allergen-stimulated Th2 cells enhanced IL-13 cytokine production. Furthermore, the marked inhibition of IL-13 production by 


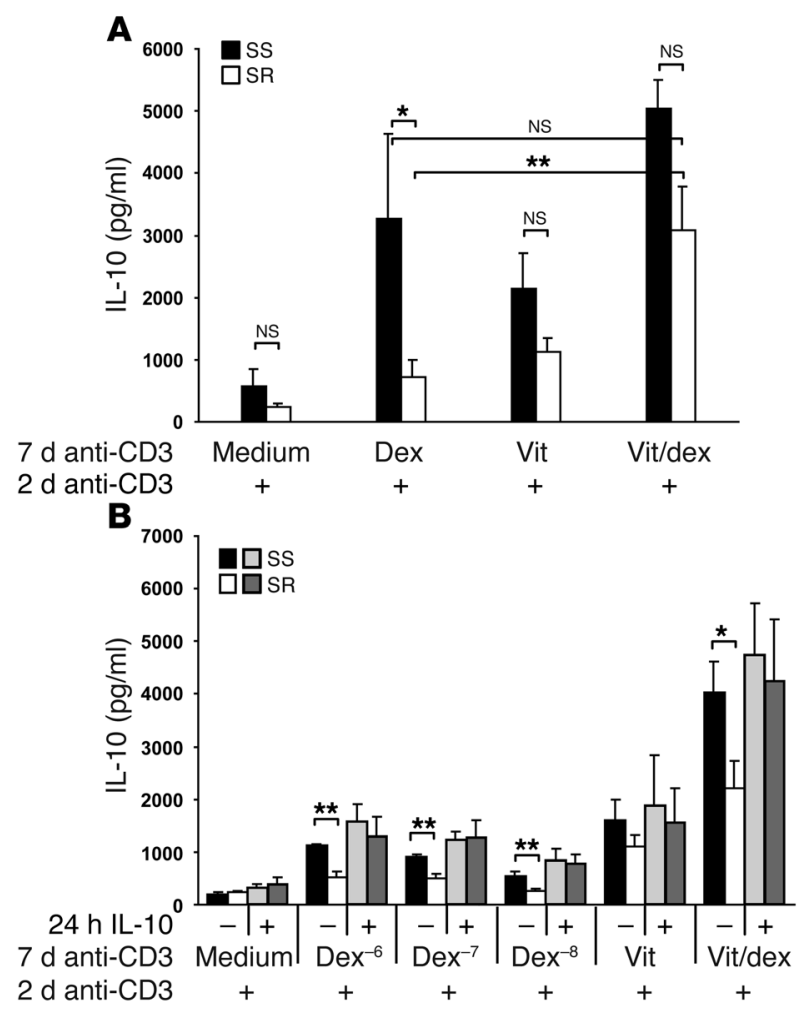

Th2 cells observed in the presence of IL-10-secreting Tregs was completely overcome by the addition of anti-IL-10R mAbs but not by isotype-matched control antibodies (Figure $3 \mathrm{H}$ ).

In addition to their ability to inhibit Th2 responses, IL-10secreting Tregs also inhibited IFN- $\gamma$ production by $\mathrm{T}$ cells in anti-CD3-driven stimulation cultures. Again, this inhibition was reversed by an anti-IL-10 receptor antibody but not by a neutralizing anti-TGF- $\beta$ antibody (Figure $2 \mathrm{C}$ ). Anti-TGF- $\beta$ also failed to reverse IL-10-secreting Treg-mediated inhibition of Th2 cytokine production in this anti-CD3-driven culture system (Figure 2C). These data further emphasize that IL-10-secreting Tregs represent a population distinct from previously described naturally occurring and Th3 Treg populations.

Vitamin D 3 enhances IL-10 synthesis by $C D 4^{+} T$ cells from SR patients. We previously demonstrated that $\mathrm{CD} 4^{+} \mathrm{T}$ cells from SR patients show a statistically significant reduction in their capacity to respond to dexamethasone for induction of IL-10 synthesis in comparison with SS patients (14). We therefore tested whether vitamin D3 could enhance IL-10 synthesis in the SR cultures stimulated with anti-CD3 and APCs. Mean data from 8 SR patient cell cultures is shown in Figure 4A. The poor response of CD4 ${ }^{+} \mathrm{T}$ cells from SR patients to dexamethasone in producing IL-10 was greatly enhanced by the addition of Vitamin D3 to the cultures, restoring IL-10 levels to those seen in cultures of cells from SS patients stimulated with dexamethasone alone such that these 2 groups were not significantly different. However, under none of the experimental conditions tested was IL-10 synthesis in the SR patient cultures fully restored to the levels observed in $\mathrm{CD}^{+} \mathrm{T}$ cells derived from SS patients.

Pretreatment with IL-10 fully restores the capacity of $C D 4^{+} T$ cells from $S R$ patients to respond to dexamethasone for induction of $I L-10$ synthesis. Since the initial development of murine IL-10-secreting Tregs in the presence of dexamethasone and vitamin D3 is IL-10 depen-

\section{Figure 4}

Enhancement of glucocorticoid-induced IL-10 synthesis by T cells from SR asthma patients with vitamin D3 and pretreatment with IL-10. (A) CD4+ T cells from SS $(n=4)$ and GR $(n=8)$ asthma patients were cultured with anti-CD3, APCs, IL-2, IL-4, and the indicated combinations of $10^{-7} \mathrm{M}$ dexamethasone and $5 \times 10^{-7} \mathrm{M}$ vitamin $\mathrm{D} 3$ for 7 days. Cells were recultured at $1 \times 10^{6} \mathrm{cells} / \mathrm{ml}$ with anti-CD3 and IL-2 alone, and 48-hour culture supernatants were assayed for IL-10 content by ELISA. One patient was tested 2 different times at an interval of 1 year. (B) CD4+ T cells from SS $(n=4)$ and SR $(n=6)$ asthma patients were cultured with APCs overnight in medium or with $2 \mathrm{ng} / \mathrm{ml} \mathrm{IL-10,} \mathrm{washed}$ and cultured with anti-CD3, IL-2, IL-4, and the indicated concentrations of dexamethasone, $5 \times 10^{-7} \mathrm{M}$ vitamin $\mathrm{D} 3$, or $1^{-7} \mathrm{M}$ dexamethasone plus vitamin D3 for 7 days. Cells were recultured with anti-CD3 and IL-2 alone and 48-hour culture supernatants assayed by ELISA. ${ }^{*} P<0.05$; ${ }^{* *} P<0.01$ using 2-tailed Student's $t$ test.

dent (25), we investigated whether pretreatment with IL-10 could further enhance the capacity of SR CD4 $4^{+} \mathrm{T}$ cells to produce IL-10 when stimulated in the presence of dexamethasone. $T$ cells were incubated overnight either in medium or with $2 \mathrm{ng} / \mathrm{ml} \mathrm{IL-10} \mathrm{and}$ then washed prior to polyclonal stimulation in the presence of the indicated combinations of dexamethasone and vitamin D3 for 7 days. All culture groups were then restimulated for 48 hours with anti-CD3 and IL-2 in the absence of the drugs. Following overnight preculture in medium prior to stimulation with anti-CD3 and dexamethasone plus vitamin D3, a clear difference in IL-10 synthesis was still maintained between the SR and SS patient groups $(P<0.01$; Figure 4B). In contrast, overnight pulsing with IL-10 prior to stimulation in the presence of dexamethasone alone fully restored IL-10 synthesis by $\mathrm{CD}^{+} \mathrm{T}$ cells from SR patients to the levels seen in SS patients. In addition, IL-10 pretreatment and subsequent stimulation in the presence of dexamethasone plus vitamin D3 further enhanced levels of IL-10 synthesis in SR CD4 ${ }^{+}$ $\mathrm{T}$ cell cultures. IL-10 pretreatment did not, however, significantly affect the production of IL-10 by $\mathrm{CD}^{+} \mathrm{T}$ cells from SS patients stimulated in the presence of the 2 drugs (Figure 4B).

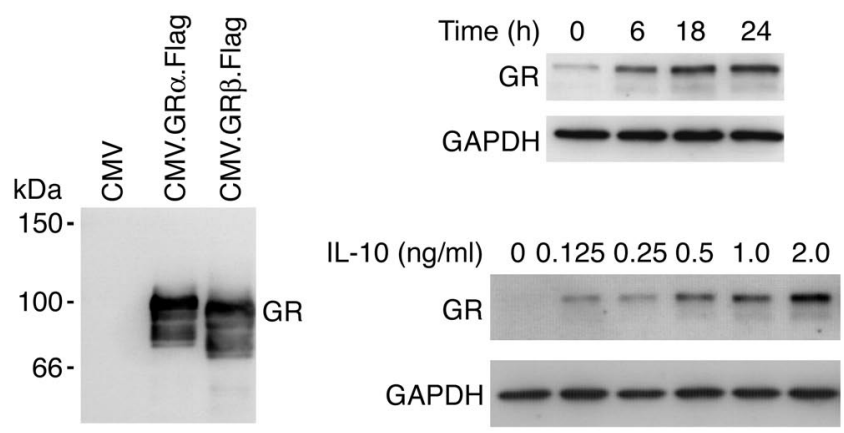

Figure 5

IL-10 enhances GR expression in CD4 ${ }^{+} \mathrm{T}$ cells. Purified CD4+ $\mathrm{T}$ cells were cultured in (a) medium (0 hours) or with $2 \mathrm{ng} / \mathrm{ml} \mathrm{IL-10} \mathrm{for} \mathrm{the}$ indicated time periods (in hours) or (b) medium or the indicated concentrations of IL-10 for 18 hours prior to analysis of GR and GAPDH levels by Western blotting. Data shown are from 2, and representative of 4 , healthy nonasthmatic donors. Identification of the immunoreactive protein as GR $\alpha$ was permitted by comparison of migration of native extract with extracts of cells transiently transfected with cDNAs encoding FLAG-tagged GR $\alpha$ and GR $\beta$. CMV, cytomegalovirus. CMV.GR $\alpha$. Flag, CMV promotor driving the expression of full-length $\mathrm{GR} \alpha$ engineered to include the 8-aa FLAG epitope. 


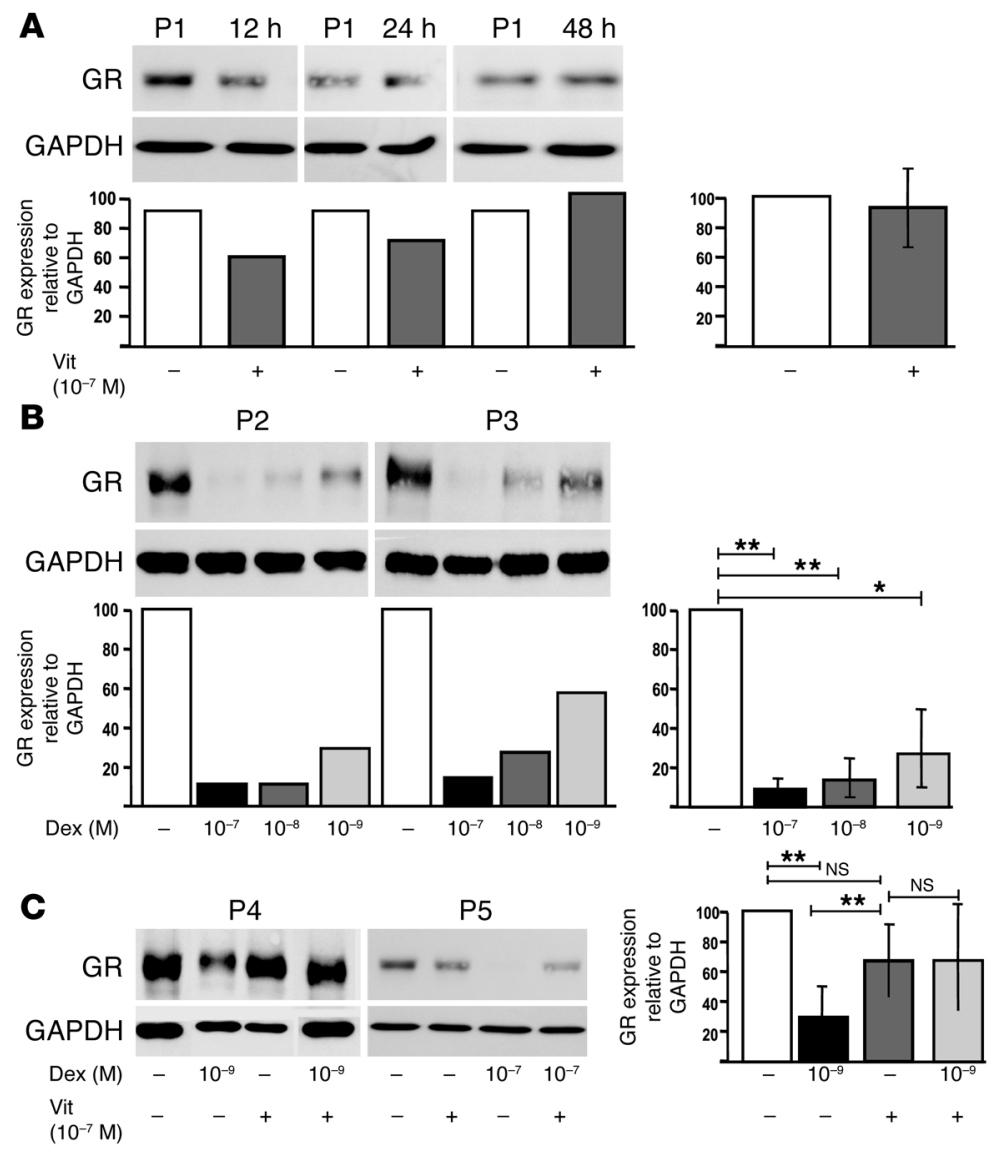

Figure 6

Vitamin D3 does not increase GR expression in CD4+ $T$ cells but prevents downregulation by dexamethasone. (A) $\mathrm{CD} 4^{+} \mathrm{T}$ cells were cultured in medium $(-)$ or with $10^{-7} \mathrm{M}$ vitamin D3 (+) for 12, 24, or 48 hours and then analyzed for GR and GAPDH by Western blot. Data from a representative donor (P1) and densitometry analysis of the ratio of GR to GAPDH is shown in the left panel; mean data from 4 individuals at 48 hours is shown in the right panel. (B) $C D 4^{+} \mathrm{T}$ cells were cultured without or with dexamethasone for 48 hours prior to Western blot analysis. Data from 2 representative individuals ( $P 2$ and $P 3$, left panel) and mean data from 4 individuals (right panel) are shown. (C) Culture of $\mathrm{CD}^{+} \mathrm{T}$ cells with vitamin D3, dexamethasone, or both drugs for 48 hours. Western blot analysis from 2 representative individuals ( $\mathrm{P} 4$ and $\mathrm{P} 5$; left panel) and mean data from 7 individuals (right panel) are shown. ${ }^{\star} P<0.05 ;{ }^{* \star} P<0.001$.
We investigated whether vitamin D3 might also act to increase GR expression since topical administration of calcitriol to patients with psoriasis has been shown to increase IL-10 locally in the skin (33). Although this was not the case (Figure 6A), we observed, as independently reported in certain cell lines (34), that the culture of CD $4^{+} \mathrm{T}$ cells with glucocorticoids leads to a dose-dependent decrease in GR $\alpha$ (Figure 6B). Strikingly, vitamin D3 abrogated the profound downregulation of GR $\alpha$ caused by dexamethasone (Figure 6C), suggesting a potential mechanism whereby vitamin D3 may contribute to the efficacy of dexamethasone in promoting glucocorticoid-induced IL-10 synthesis.

Oral administration of vitamin D3 enhances the responsiveness to glucocorticoids for induction of IL-10 synthesis. In a proof of concept study, the effect of ingestion of vitamin D3 in SR asthmatic patients was investigated. Subjects were bled prior to vitamin D3 ingestion and on days 1,3 , and 7 after ingestion of $0.5 \mu \mathrm{g}$ vitamin D3 daily. $T$ cells were stimulated with anti-CD3 in the presence or absence of dexamethasone for 7 days, using methodology identical to that used in earlier experiments, to determine any differences in reactivity to dexamethasone. Cell pellets were prepared at this time for mRNA extraction, or cells were recultured in the absence of drugs and analyzed for changes in IL-10 protein at 48 hours. In all SR individuals tested, IL-10 expression by $\mathrm{CD}^{+} \mathrm{T}$ cells was enhanced following vitamin D3 ingestion as assessed by intracellular cytokine staining, ELISA, and quantitative PCR (Figure 7). In 2 donors (SR1 and SR2), this enhancement was sustained on days 1 and 3 as well as day 7 in SR 2 over a range of dexamethasone concentrations. In the third donor, SR3, enhancement was observed on day 3 alone. Similar protein data were observed in 4 healthy individuals tested in a pilot study (Supplemental Figure 1; supplemental material available online with this article; doi:10.1172/JCI21759DS1; RNA not assayed in this earlier study). These preliminary data provide encouraging evidence of the capacity of vitamin D3 to promote responsiveness to glucocorticoids for the induction of IL-10 synthesis.
Effects of IL-10 and vitamin D3 on the expression of the glucocorticoid receptor. Since we have implicated deficient IL-10 production by $\mathrm{T}$ cells in the mechanism of clinical glucocorticoid resistance, we hypothesized that IL-10 may regulate responsiveness of T cells to glucocorticoids and therefore tested to determine whether IL-10 modulates the expression of the glucocorticoid receptor (GR). Western blotting studies of total cell lysates from $\mathrm{CD}^{+} \mathrm{T}$ cells from nonasthmatic healthy individuals demonstrated an IL-10 concentration-dependent induction of GR $\alpha$ expression in comparison with cells cultured in medium alone (Figure 5A). Induction was already detectable at 6 hours but most marked following 18 and 24 hours of culture with IL-10. GR $\beta$ expression was not detected in the $\mathrm{T}$ cell lysates (Figure $5 \mathrm{~B}$ ) although it could be detected in U293 cells transfected with cDNA encoding FLAG-tagged GR $\beta$, indicating very low expression of GR $\beta$ in human peripheral $\mathrm{CD} 4^{+} \mathrm{T}$ cells.

\section{Discussion}

The present study demonstrates that human IL-10-secreting Tregs induced ex vivo following stimulation in the presence of vitamin D3 and dexamethasone secrete high levels of IL-10 that is associated with a potent capacity to inhibit immune responses implicated in the pathogenesis of allergic and asthmatic disease. Specifically, allergen-induced cytokine production by Th2 cells was inhibited by allergen-induced IL-10-secreting Tregs in an IL-10-dependent manner. Furthermore, we demonstrated that by combining preincubation with IL-10 and addition of vitamin D3 to the T cell stimulation cultures, a defect in glucocorticoid-induced IL-10 production by $\mathrm{CD}^{+} \mathrm{T}$ cells from SR asthma patients was fully overcome. This may result from our findings that IL-10 increased GR expression by human $\mathrm{CD}^{+} \mathrm{T}$ cells while vitamin D3 overcame ligand-induced downregulation of GR. Strikingly, ingestion of vitamin D3 by SR asthmatic patients enhanced subsequent responsiveness to dexa- 


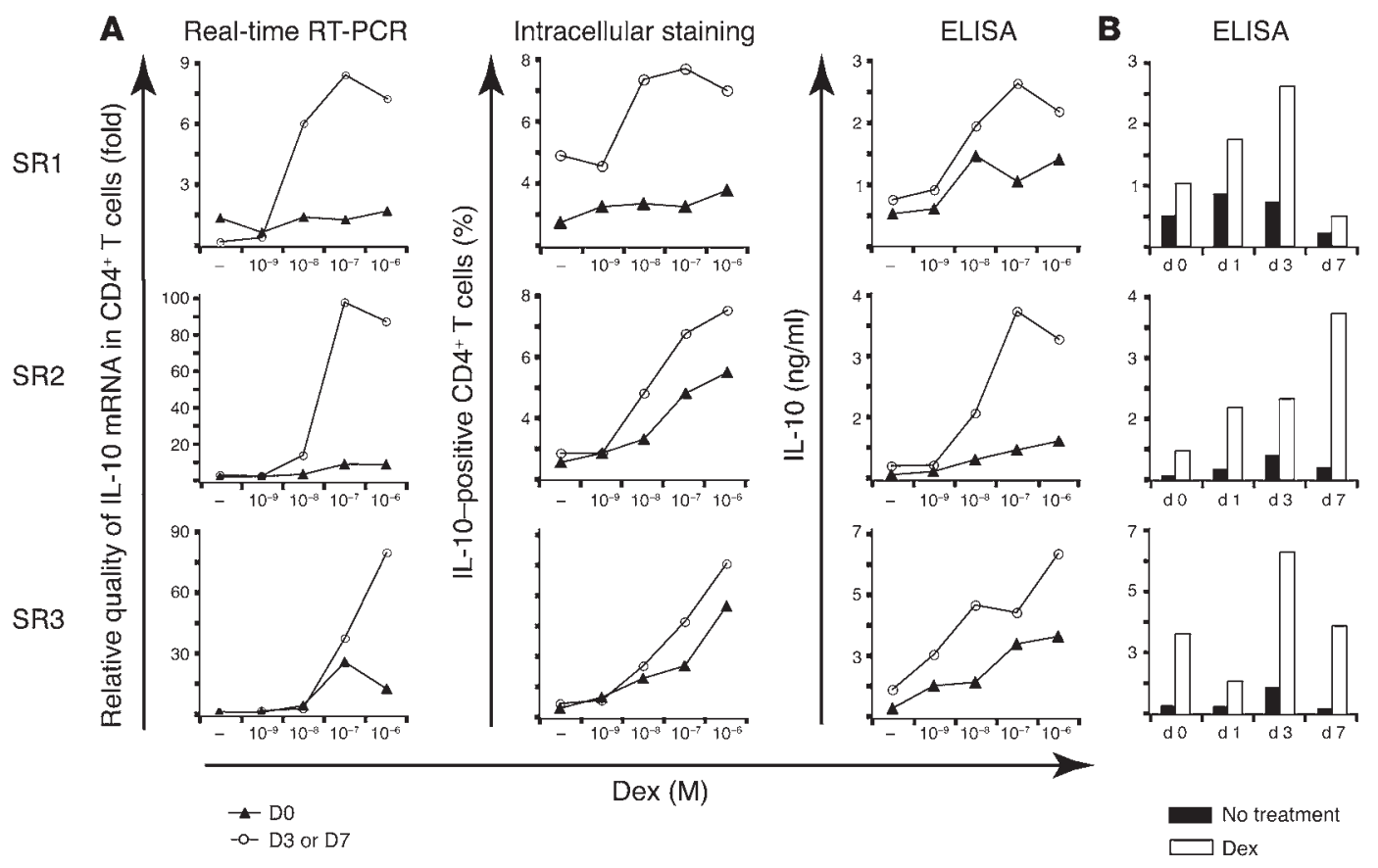

Figure 7

Ingestion of vitamin D3 enhances responsiveness to dexamethasone for induction of IL-10 synthesis. CD4+ T cells isolated prior to (day 0 [d 0]) or 1,3 , or 7 days after ingestion of vitamin D3 were cultured with anti-CD3 and IL-2 with or without the indicated concentrations of dexamethasone for 7 days. Cells were then assayed for mRNA at this time or recultured for 48 hours with anti-CD3 and IL-2 and analyzed for expression of IL-10 by intracellular cytokine staining and ELISA. (A) IL-10 responses to a range of dexamethasone concentrations were assessed, and data are shown at the time of maximal induction for each donor (SR1 and SR3, day 3; SR2, day 7). mRNA levels are expressed relative to day 0, medium (-). (B) IL-10 responses to a single dose of dexamethasone $\left(10^{-6}\right.$ or $\left.10^{-7} \mathrm{M}\right)$ over time.

methasone for the induction of IL-10 synthesis, highlighting the potential clinical relevance of these observations. IL-10-secreting Tregs may hold therapeutic potential for asthma and allergic diseases, and our findings offer potential novel strategies for reversing glucocorticoid resistance.

We have previously described the capacity of vitamin D3 and dexamethasone to induce IL-10-producing $\mathrm{T}$ cells from both murine and human $\mathrm{CD}^{+} \mathrm{T}$ cells (25) and show here that the human IL-10-producing Tregs exhibit regulatory activity in vitro. Importantly, human IL-10-secreting Tregs could suppress previously activated antigen-specific Th2 cells, the therapeutic target in allergy and asthma. This inhibition of cytokine secretion from allergen-specific Th2 cells by IL-10-secreting Tregs was IL-10 dependent in this system. Since these cultures included APCs, this IL-10-dependent suppression may have been mediated via the well established effects of IL-10 on APCs (5).

$\mathrm{CD} 4{ }^{+} \mathrm{CD} 25^{+}$Tregs suppress allergen-induced proliferation and Th2 cytokine production by peripheral $\mathrm{CD} 4^{+} \mathrm{T}$ cells independently of IL-10 secretion (35). Here, we compared human IL-10-secreting Tregs and $\mathrm{CD} 4^{+} \mathrm{CD} 25^{+} \mathrm{T}$ cells and show that unlike IL-10-secreting Tregs, expression of IL- 10 by $\mathrm{CD}^{+} \mathrm{CD} 25^{+}$Tregs was minimal. Furthermore, unlike CD $4^{+} \mathrm{CD} 25^{+}$Tregs, IL-10-secreting Tregs did not express high levels of mRNA encoding the forkhead winged helix transcription factor FoxP3. Thus, although FoxP3 appears to be important for the development and function of naturally occurring $\mathrm{CD}^{+} \mathrm{CD} 25^{+} \mathrm{T}$ cells (31), in vitro-derived IL-10-secreting Tregs appear to have regulatory function despite low levels of Foxp3 expression. We further demonstrate that drug-induced IL-10-secret- ing Tregs are distinct for TGF- $\beta$ synthesizing Th 3 cells, as they show no increased synthesis of TGF- $\beta$, and neutralizing antibody to this cytokine does not modify their inhibitory function (17).

Although inhaled glucocorticoids are very effective for the treatment of most patients with asthma, an important subgroup of patients require oral glucocorticoids to control their disease at the risk of considerable side effects, and a subgroup of these patients fail to show clinical improvement even with high-dose glucocorticoid therapy (13). These patients represent an important healthcare problem and, consequently, if the response to glucocorticoid treatment could be enhanced in such patients, this would represent a major therapeutic advance. Our data imply that induction of IL-10 synthesis may contribute to the clinical efficacy of glucocorticoid therapy in asthma since IL-10 plays an essential role in the functional activities of IL-10-secreting Tregs and patients who fail to respond clinically to glucocorticoids also fail to respond ex vivo to glucocorticoids for induction of IL-10 synthesis (14). We now present evidence that it is possible to reverse this defect. First, addition of vitamin D3 to T cell cultures polyclonally stimulated with anti-CD3 and dexamethasone enhanced IL-10 synthesis in the SR cultures, restoring them to levels observed in SS cultures stimulated in the presence of dexamethasone alone. Secondly, administration of vitamin D3 orally to SR patients and healthy donors modified subsequent responsiveness of their $\mathrm{CD}^{+} \mathrm{T}$ cells to glucocorticoids for induction of IL-10 synthesis in all individuals tested. Vitamin D3 is at present occasionally administered to severe asthmatic patients as part of a prophylactic regimen against glucocorticoid-induced osteoporosis (36), and our studies suggest 
an additional potential benefit of such treatment. These data with vitamin D3 establish an important precedent showing that it is possible to boost IL-10 synthesis in this important patient group. However, it may also be possible to achieve similar cooperative effects between glucocorticoids and other drugs for induction of IL-10-secreting Tregs. Indeed, our recent studies demonstrate a similar capacity upon combining glucocorticoids with long-acting $\beta_{2}$-agonists to induce an IL-10-secreting Treg profile (37).

The mechanisms by which IL-10 and vitamin D3 enhance glucocorticoid-induced IL-10 synthesis were investigated. We hypothesized that IL-10 itself may be regulating responsiveness to glucocorticoids and now demonstrate a concentration-dependent effect of IL-10 on GR $\alpha$ expression by human CD4 ${ }^{+} \mathrm{T}$ cells. The possible functional significance of this observation is supported by an independent study that demonstrated that IL-10 increased the sensitivity of human monocytes to dexamethasone and increased the number of tritiated dexamethasone binding sites in U937 cells (38). The antibody used in our Western blotting detects both $\alpha$ and $\beta$ spliced variants of GR, and these forms are readily distinguishable in Western blotting by virtue of their size difference. We consistently observed enhancement of GR $\alpha$ in IL-10-treated T cells whereas the GR $\beta$ variant remained undetectable by Western blot in agreement with several independent studies (ref. 39 and references therein). Two studies have used immunohistochemistry to detect GR expression in tissues, with both suggesting that less GR $\alpha$ is available in SR. One study demonstrated that glucocorticoid resistance in asthma is associated with elevated in vivo expression of GR $\beta$ relative to GR $\alpha$ in skin biopsies (40) while the second showed that airway T cells from SR patients showed increased GR $\beta$ expression in comparison with cells from glucocorticoid-sensitive asthmatics or control subjects (41). Notably, however, although elevated GR $\beta$ was also reported in blood T cells from this patient group, the levels were much lower than those observed in airway T cells. Thus GR $\beta$ is expressed at extremely low levels in normal cells but may be upregulated in SR asthma $(40,42)$. GR $\beta$ has been proposed to act as a dominant-negative form of GR operative at glucocorticoid-response elements (43). Thus, the upregulation of GR $\alpha$ observed by Western blot may alter the GR $\alpha$ to GR $\beta$ ratio and therefore partially restore responsiveness. In studies into the mechanism of vitamin D3 action, we observed that dexamethasone induces a dose-dependent and profound downregulation of GR in primary human $\mathrm{CD}^{+} \mathrm{T}$ cells. Strikingly, coincubation of $\mathrm{CD} 4^{+} \mathrm{T}$ cells with vitamin D3 and dexamethasone was observed to rescue GR expression and lead to a less severe decrease of GR expression in the $\mathrm{CD}^{+} \mathrm{T}$ cell population. We found no direct effect of vitamin $\mathrm{D} 3$ on GR expression by human $\mathrm{CD}^{+} \mathrm{T}$ cells. We propose that these observations may, in part, explain the capacity of vitamin D3 to promote glucocorticoid-induced IL-10 synthesis.

It will be important to determine whether the defect in glucocorticoid-induced IL-10 synthesis observed in some asthmatic patients is a common feature of other immune-mediated inflammatory diseases that exhibit clinical refractoriness to glucocorticoid therapy, e.g., inflammatory bowel disease and rheumatoid arthritis (44). If failure to induce IL-10 ex vivo also correlates with clinical refractoriness to glucocorticoid therapy in other inflammatory conditions, then analysis of IL-10 synthesis may ultimately prove useful in disease management. For example, it could act as a useful predictive tool in determining which patients will be unresponsive to glucocorticoid therapy so that alternative treatment regimens can be introduced sooner.
Both our own and independent studies suggest the capacity of both glucocorticoids and vitamin D3 to promote IL-10 synthesis in vivo. Other regimens, such as peptide therapy in murine models or allergen immunotherapy in allergic patients, may also induce IL-10secreting Tregs (45-47). However, allergen immunotherapy carries a risk of severe allergic reactions or anaphylaxis (48), which precludes its use for severe asthma in current dose regimens, and peptide therapy for autoimmune diseases carries similar risks $(49,50)$. Combination with drug therapy might allow safer use of immunotherapy and promote the induction of IL-10-secreting Tregs. Other strategies have been adopted for investigating IL-10-secreting Tregs in vitro in animal models and support a therapeutic role of IL-10 synthesizing $T$ cells in alleviating allergic symptoms $(6,51-53)$. For example, 1 recent study demonstrated that $\mathrm{CD} 4^{+} \mathrm{T}$ cells engineered to express IL-10 prevent Th2-driven airway hyperresponsiveness and inflammation (12). Finally, although 2 groups suggest that IL-10 may be required in the development of murine airway hyperresponsiveness $(54,55)$, these represent extremes of either transgenic overexpression or the complete absence of IL-10 in the airways and therefore do not represent physiological conditions. We would argue that the challenge for the future will be to harness these beneficial drug-mediated effects and induce allergen-specific IL-10 synthesis in a local and controlled manner at the time of allergen exposure (6).

In conclusion, we show that human IL-10-secreting Tregs are distinct from $\mathrm{CD}^{+} \mathrm{CD} 25^{+} \mathrm{T}$ cells and TGF- $\beta$-secreting Th 3 cells and show in vitro suppressive activity against allergen-specific Th2 cells. Furthermore, we show that both vitamin D3 and IL-10 can overcome the defect in IL-10 production by $\mathrm{CD}^{+} \mathrm{T}$ cells from SR asthma patients. Induction of antigen-specific IL-10-secreting Tregs is an appealing future therapeutic area for asthma and allergic diseases.

\section{Methods}

Patient details. PBMCs were obtained from healthy individuals and patients attending the Asthma Clinic at Guy's Hospital, London, United Kingdom. Asthma was defined by American Thoracic Society criteria as reversible obstruction ( $\geq 15 \%$ ) of the airways (14). Glucocorticoid resistance (SR) was defined as the failure of forced expired volume in 1 second $\left(\mathrm{FEV}_{1}\right)$ to improve by $15 \%$ or more from a baseline of $75 \%$ or less after 14 days of $40 \mathrm{mg}$ /day oral prednisolone, and glucocorticoid sensitivity (SS) was defined as an improvement of $25 \%$ or more in $\mathrm{FEV}_{1}$ following an identical course of prednisolone treatment. PBMCs were obtained from 7 SR patients ( 2 female, 5 male; mean age \pm SD, $54 \pm 15$; mean basal $\mathrm{FEV}_{1}, 55 \% \pm 20 \%$ of predicted; and range of prednisolone reversibility, 0-14\%) and from 5 SS patients ( 2 female, 3 male; mean age, $50 \pm 10$; mean basal $\mathrm{FEV}_{1}, 46 \% \pm 24 \%$ of predicted; and range of prednisolone reversibility, $26 \%$ to $>100 \%)$. All patients were nonsmokers and using inhaled (400-1000 $\mu \mathrm{g})$ glucocorticoids daily and $\beta 2$-agonists as required. Patients taking oral glucocorticoids within 1 month of study were excluded. All donors signed a consent form approved by the Ethics Committee at Guy's Hospital.

Cell purification and culture. PBMCs were isolated as previously described (3). $\mathrm{CD}^{+} \mathrm{T}$ cells were purified by positive selection using Dynabeads (Dynal Biotech; typical purity, 99.5\%). Samples containing CD4+ $\mathrm{T}$ cells plus APCs, unless otherwise specified, were prepared by negative depletion using $\mathrm{CD}^{+}$Dynabeads (3). $\mathrm{CD} 4^{+} \mathrm{CD} 25^{+} \mathrm{T}$ cells were isolated as previously described (35).

We stimulated $1 \times 10^{6}$ cells $/ \mathrm{ml} \mathrm{CD} 4^{+} \mathrm{T}$ cells or $\mathrm{CD} 4^{+} \mathrm{T}$ cells plus APCs with $1 \mu \mathrm{g} / \mathrm{ml}$ plate-bound or soluble anti-CD3 (OKT-3), respectively, $50 \mathrm{U} / \mathrm{ml} \mathrm{IL-2}$ (EuroCetus), $10 \mathrm{ng} / \mathrm{ml} \mathrm{IL-4} \mathrm{(NBS),} \mathrm{calcitriol} \mathrm{(Vitamin} \mathrm{D3;}$ $\mathrm{BIOMOL}$ ), and dexamethasone (Sigma-Aldrich) as indicated. Cells were restimulated with cross-linked anti-CD3 and the same stimuli as in the 
first culture $(3,25)$. Where indicated, cells were recultured after 7 days with cross-linked anti-CD3 and IL-2 alone and supernatants harvested at 48 hours for cytokine analysis.

To generate allergen-specific T cell lines, PBMCs were obtained from atopic volunteers. Atopy was defined as previously described (3). We cultured $2 \times 10^{6}$ cells $/ \mathrm{ml} \mathrm{CD} 4$ plus APCs with $10 \mu \mathrm{g} / \mathrm{ml}$ of allergen and $10 \mathrm{ng} / \mathrm{ml}$ IL-4. The Th2 group also received $5 \mu \mathrm{g} / \mathrm{ml}$ anti-IFN- $\gamma$ and anti-IL-12 (both from BD Biosciences - Pharmingen), and the regulatory group received $10^{-7} \mathrm{M}$ dexamethasone and $10^{-7} \mathrm{M}$ vitamin $\mathrm{D} 3$. On day 7 , cells were washed and recultured under the same initial culture conditions plus fresh allergen and irradiated APCs (T cell-depleted PBMCs; 300 Gy). T cell lines were also derived from healthy volunteers by stimulating CD4 and APCs with anti-CD3 and IL-2 in the presence of IL-4 ( $\left.\mathrm{T}_{\mathrm{IL}-4}\right)$ or IL-4, vitamin D3, and dexamethasone (IL-10-secreting Tregs).

Functional assays of regulatory function. On day 14 , fresh autologous CD4 ${ }^{+}$ $\mathrm{T}$ cells were purified and labeled with $2 \mu \mathrm{M}$ CFSE (Invitrogen Corp.), and $2 \times 10^{5}$ cells were cocultured with $5 \times 10^{4}$ autologous irradiated APCs and $5 \times 10^{4} \mathrm{~T}_{\mathrm{IL}-4}$ or IL-10-secreting Tregs as indicated. Cultures were stimulated with soluble anti-CD3, with or without $5 \mu \mathrm{g} / \mathrm{ml}$ anti-IL-10 receptor (3F9-2; DNAX), $5 \mu \mathrm{g} / \mathrm{ml}$ anti-TGF- $\beta$ (DNAX), or $5 \mu \mathrm{g} / \mathrm{ml}$ isotype control rat IgG2a (R35-9S; BD Biosciences - Pharmingen) as indicated for 6 days. Propidium iodide (Sigma-Aldrich) was then added to exclude dead cells and 10,000 CD4-CFSE-positive cells analyzed using a FACSCaliber flow cytometer (BD). The proliferation index was generated using ModFit LT software version 3.0 (Verity Software House). Alternatively, supernatants were harvested on day 3 and assayed by ELISA for cytokine content. For analysis of allergen-specific regulatory function, 14-day Th2 and IL-10-secreting Treg lines were generated. Cocultures contained the indicated combinations of $1 \times 10^{5} \mathrm{Th} 2,5 \times 10^{4} \mathrm{IL}-10$-secreting Tregs, and $1 \times 10^{5}$ autologous irradiated APCs, stimulated with $10 \mu \mathrm{g} / \mathrm{ml}$ allergen and, where indicated, $5 \mu \mathrm{g} / \mathrm{ml}$ anti-IL-10 receptor or $5 \mu \mathrm{g} / \mathrm{ml}$ isotype control rat $\mathrm{IgG}_{2 \mathrm{a}}$ added. Supernatants were harvested on day 3 for analysis of cytokine content.

Intracellularstaining. On day 7 or day 7 plus 48 hours of a further anti-CD3induced stimulation, cells were restimulated for 4 hours with $0.25 \mathrm{ng} / \mathrm{ml}$ PMA (Sigma-Aldrich) and $25 \mathrm{ng} / \mathrm{ml}$ ionomycin (Calbiochem), with monensin (Sigma-Aldrich) added for the final 2 hours. Cells were washed, fixed, and permeabilized using Cytofix/Cytoperm kit (BD Biosciences - Pharmingen) and triple-stained with fluorescently labeled monoclonal antibodies to IL-10, IL-2, IL-4, IL-13, GM-CSF (all at $100 \mathrm{ng} / \mathrm{sample}$ ), or IFN- $\gamma(250 \mathrm{ng} /$ sample) (BD Biosciences - Pharmingen) (3, 25). Staining with isotype control antibodies (BD Biosciences - Pharmingen) was performed in all experiments. Dead cells (7-aminoactinomycin D [7-AAD] positive; Sigma-Aldrich) were gated out and 10,000 live cells analyzed by flow cytometry.

Cytokine analysis. IL-5, IL-10, IL-13, and IFN- $\gamma$ were measured using ELISA and matched antibody pairs (BD Biosciences - Pharmingen), with reference to commercial standards (R\&D Systems). The lower limit of detection for IFN- $\gamma$ and IL-10 was $50 \mathrm{pg} / \mathrm{ml}$, for IL-5, $100 \mathrm{pg} / \mathrm{ml}$, and for IL-13, $100 \mathrm{pg} / \mathrm{ml}$. When less than $100 \mu \mathrm{l}$ supernatant was available, a human Th1/Th2 cytometric bead array kit (BD Biosciences - Pharmingen) was used. TGF- $\beta 1$ was measured using the TGF- $\beta 1$ Emax Immunoassay System (Promega). For assay of total active TGF- $\beta 1$, samples were diluted $1: 5$, treated with $1 \mathrm{~N} \mathrm{HCl}$, then neutralized with $1 \mathrm{~N} \mathrm{NaOH}$.

Vitamin D 3 treatment of healthy and SR asthmatic volunteers. The study was approved by the Research Ethics Committee of Guy's Hospital and informed consent obtained from volunteers. Four healthy volunteers (1 female, 3 male; $36-48$ years old) and 3 SR patients ( 1 female, 2 male; 50-60 years old) were given $0.5 \mu \mathrm{g} / \mathrm{day}(2 \times 0.25 \mu \mathrm{g})$ oral calcitriol for 7 days. PBMCs were obtained at days 0 (before treatment) and days 1,3 , and 7 . Donors were always bled between 9:30 am and 10:30 am to control for any influence of diurnal changes. $\mathrm{CD} 4^{+} \mathrm{T}$ lymphocytes plus APCs were stimulated for 7 days with $1 \mu \mathrm{g} / \mathrm{ml}$ plate-bound anti-CD3, $50 \mathrm{U} / \mathrm{ml} \mathrm{IL-2,} \mathrm{and}$ varying concentrations of dexamethasone. On day 7 , cells were washed and restimulated with PMA-ionomycin for 4 hours (cell pellets kept for mRNA extraction) or cross-linked with anti-CD3 and IL-2 for a further 48 hours. Cells were harvested at 48 hours for intracellular staining for IL-10 and culture supernatants harvested for cytokine analysis.

Western analysis of GR protein. CD4 ${ }^{+} \mathrm{T}$ cells were incubated with human recombinant IL-10 (R\&D Systems), vitamin D3, and/or dexamethasone for the indicated periods ( 0 to 72 hours), then they were washed, soluble cell proteins were extracted, and Western blot was performed as previously described (56). GR was detected using a mouse monoclonal antibody (BD Transduction Laboratories; BD Biosciences - Pharmingen) and goat antimouse horseradish peroxidase-conjugated secondary antibody. Immunoreactive complexes were revealed by ECL (Amersham Biosciences) and visualized by autoradiography. Discrimination between GR $\alpha$ and GR $\beta$ was facilitated by the use of FLAG epitope-tagged GR $\alpha$ and GR $\beta$ cDNAs. An empty vector (pcDNA3; Invitrogen Corp.) was used as a negative control. Overexpression of these cDNAs in U293 cells permitted Western blotting with either anti-FLAG (Sigma-Aldrich; not shown) or anti-GR (56). The different migration of these 2 proteins and comparison with native protein allowed discrimination among spliced variants.

Real-time RT-PCR. RNA was extracted from cell pellets using either the Absolutely RNA kit (Stratagene) or the RNeasy Mini kit (QIAGEN) according to the manufacturers' instructions. The RNA was quantified using Ribogreen RNA quantification kit (Molecular Probes). For each sample, $250 \mathrm{ng}$ of RNA was reverse transcribed in a total volume of $30 \mu \mathrm{l}$ using random hexamer primers (Fermentas Life Sciences). Real-time RTPCR was performed in triplicate using an Applied Biosystems 7900 HT system and carboxy fluorescein-labeled (FAM-labeled) Assay-on-Demand reagent sets (Applera Corp.) for the following: FoxP3, Hs00203958_m1; IL-10, Hs00174086_m1; and TGF- $\beta$, Hs99999918_m1. Real-time RT-PCR reactions were multiplexed using VIC-labeled $18 s$ primers and probes (Hs99999901_s1) as endogenous control and analyzed using SDS software version 2.1 (Applied Biosystems) according to the $2^{-(\Delta \Delta C t)}$ method.

Statistics. Results are presented as mean \pm SEM. Differences between groups were assessed using the 2-tailed paired Student's $t$ test. Differences were considered significant at the $95 \%$ confidence level.

\section{Acknowledgments}

E. Xystrakis and S. Kusumakar were funded by Asthma-UK $(00 / 023$ and $03 / 065)$. T. Adikibi was funded by a UK Medical Research Council Realising Our Potential Award. T.H. Lee and P. Lavender were funded by a UK Medical Research Council Programme Grant.

Received for publication March 31, 2004, and accepted in revised form October 11, 2005.

Address correspondence to: Catherine M. Hawrylowicz, Medical Research Council and Asthma-UK Centre in Allergic Mechanisms of Asthma, Department of Asthma, Allergy and Respiratory Science, Guy's Hospital, King's College London, London SE1 9RT, United Kingdom. Phone: 0207-188-0599; Fax: 0207-403-8640; E-mail: catherine.hawrylowicz@kcl.ac.uk.

Sandra Boswell and Emma Peek contributed equally to this work.

Emmanuel Xystrakis and Siddharth Kusumakar are joint first authors. 
1. Wills-Karp, M. 1999. Immunologic basis of antigen-induced airway hyperresponsiveness. Annu. Rev. Immunol. 17:255-281.

2. Umland, S.P., Schleimer, R.P., and Johnston, S.L. 2002. Review of the molecular and cellular mechanisms of action of glucocorticoids for use in asthma. Pulm. Pharmacol. Ther. 15:35-50.

3. Richards, D.F., Fernandez, M., Caulfield, J., and Hawrylowicz, C.M. 2000. Glucocorticoids drive human CD8(+) T cell differentiation towards a phenotype with high IL-10 and reduced IL-4, IL-5 and IL-13 production. Eur. J. Immunol. 30:2344-2354.

4. John, M., et al. 1998. Inhaled corticosteroids increase interleukin-10 but reduce macrophage inflammatory protein- $1 \alpha$, granulocyte-macrophage colony stimulating factor and interferon- $\gamma$ release from alveolar macrophages in asthma. Am. J. Respir. Crit. Care Med. 157:256-262.

5. Moore, K.W., de Waal Malefyt, R., Coffman, R.L., and O'Garra, A. 2001. Interleukin-10 and the interleukin-10 receptor. Annu. Rev. Immunol. 19:683-765.

6. Hawrylowicz, C.M., and O'Garra, A. 2005. Potential role of interleukin-10-secreting regulatory $\mathrm{T}$ cells in allergy and asthma. Nat. Rev. Immunol. 5:271-283.

7. Borish, L., et al. 1996. Interleukin-10 regulation in normal subjects and patients with asthma. J. Allergy Clin. Immunol. 97:1288-1296.

8. Lim, S., Crawley, E., Woo, P., and Barnes, P.J. 1998. Haplotype associated with low interleukin-10 production in patients with severe asthma [letter]. Lancet. 352:113.

9. Akdis, M., et al. 2004. Immune responses in healthy and allergic individuals are characterized by a fine balance between allergen-specific $T$ regulatory 1 and T helper 2 cells. J. Exp. Med. 199:1567-1575.

10. Heaton, T., et al. 2005. An immunoepidemiological approach to asthma: identification of in-vitro T-cell response patterns associated with different wheezing phenotypes in children. Lancet. 365:142-149.

11. Stampfli, M.R., et al. 1999. Interleukin-10 gene transfer to the airway regulates allergic mucosal sensitization in mice. Am. J. Respir. Cell Mol. Biol. 21:586-596.

12. Oh, J.W., et al. 2002. CD4 T-helper cells engineered to produce IL-10 prevent allergen-induced airway hyperreactivity and inflammation. J. Allergy Clin. Immunol. 110:460-468.

13. Corrigan, C.J., et al. 1991. Glucocorticoid resistance in chronic asthma. Glucocorticoid pharmacokinetics, glucocorticoid receptor characteristics, and inhibition of peripheral blood T cell proliferation by glucocorticoids in vitro. Am. Rev. Respir. Dis. 144:1016-1025.

14. Hawrylowicz, C., Richards, D., Loke, T.K., Corrigan, C., and Lee, T. 2002. A defect in corticosteroid-induced IL-10 production in T lymphocytes from corticosteroid-resistant asthmatic patients. J. Allergy Clin. Immunol. 109:369-370.

15. Kam, J.C., Szefler, S.J., Surs, W., Sher, E.R., and Leung, D.Y. 1993. Combination IL-2 and IL-4 reduces glucocorticoid receptor-binding affinity and $\mathrm{T}$ cell response to glucocorticoids. J. Immunol. 151:3460-3466.

16. Maloy, K.J., and Powrie, F. 2001. Regulatory T cells in the control of immune pathology. Nat. Immunol. 2:816-822.

17. Weiner, H.L. 2001. Induction and mechanism of action of transforming growth factor-beta-secreting Th3 regulatory cells. Immunol. Rev. 182:207-214.

18. Sakaguchi, S., et al. 2001. Immunologic self tolerance maintained by T-cell-mediated control of selfreactive $T$ cells: implications for autoimmunity and tumor immunity. Microbes Infect. 3:911-918.

19. Bacchetta, R., et al. 1994. High levels of interleukin 10 production in vivo are associated with tolerance in SCID patients transplanted with HLA mismatched hematopoietic stem cells. J. Exp. Med. 179:493-502.
20. Groux, H., et al. 1997. A CD4+ T-cell subset inhibits antigen-specific T-cell responses and prevents colitis. Nature. 389:737-742.

21. Sundstedt, A., et al. 1997. Immunoregulatory role of IL-10 during superantigen-induced hyporesponsiveness in vivo. J. Immunol. 158:180-186.

22. Papiernik, M., et al. 1997. T cell deletion induced by chronic infection with mouse mammary tumor virus spares a CD25-positive, IL-10-producing T cell population with infectious capacity. J. Immunol. 158:4642-4653.

23. Jonuleit, H., Schmitt, E., Schuler, G., Knop, J., and Enk, A.H. 2000. Induction of interleukin 10-producing, nonproliferating CD4(+) T cells with regulatory properties by repetitive stimulation with allogeneic immature human dendritic cells. J. Exp. Med. 192:1213-1222.

24. Sundstedt,A., O’Neill, E.J., Nicolson, K.S., and Wraith, D.C. 2003. Role for IL-10 in suppression mediated by peptide-induced regulatory $\mathrm{T}$ cells in vivo. J. Immunol. 170:1240-1248.

25. Barrat, F.J., et al. 2002. In vitro generation of interleukin 10-producing regulatory CD4(+) T cells is induced by immunosuppressive drugs and inhibited by T helper type 1 (Th1)- and Th2-inducing cytokines. J. Exp. Med. 195:603-616.

26. Vieira, P.L., et al. 2004. IL-10-secreting regulatory $\mathrm{T}$ cells do not express Foxp3 but have comparable regulatory function to naturally occurring CD4+CD25+ regulatory T cells. J. Immunol. 172:5986-5993.

27. Thornton, A.M., and Shevach, E.M. 1998. CD4+CD25+ immunoregulatory $\mathrm{T}$ cells suppress polyclonal $\mathrm{T}$ cell activation in vitro by inhibiting interleukin 2 production. J. Exp. Med. 188:287-296.

28. Asseman, C., Mauze, S., Leach, M.W., Coffman, R.L., and Powrie, F. 1999. An essential role for interleukin 10 in the function of regulatory $\mathrm{T}$ cells that inhibit intestinal inflammation. J. Exp. Med. 190:995-1004

29. Hara, M., et al. 2001. IL-10 is required for regulatory $\mathrm{T}$ cells to mediate tolerance to alloantigens in vivo. J. Immunol. 166:3789-3796.

30. Belkaid, Y., Piccirillo, C.A., Mendez, S., Shevach, E.M., and Sacks, D.L. 2002. CD4+CD25+ regulatory $\mathrm{T}$ cells control Leishmania major persistence and immunity. Nature. 420:502-507.

31. Ramsdell, F. 2003. Foxp3 and natural regulatory T cells: key to a cell lineage? Immunity. 19:165-168.

32. Ritz, S.A., Stampfli, M.R., Davies, D.E., Holgate, S.T., and Jordana, M. 2002. On the generation of allergic airway diseases: from GM-CSF to Kyoto. Trends Immunol. 23:396-402.

33. Kang, S., et al. 1998. Calcipotriene-induced improvement in psoriasis is associated with reduced interleukin- 8 and increased interleukin10 levels within lesions. Br. J. Dermatol. 138:77-83.

34. Burnstein, K.L., Jewell, C.M., and Cidlowski,J.A. 1990. Human glucocorticoid receptor cDNA contains sequences sufficient for receptor down-regulation. J. Biol. Chem. 265:7284-7291.

35. Ling, E.M., et al. 2004. Relation of CD4+CD25+ regulatory $\mathrm{T}$-cell suppression of allergen-driven $\mathrm{T}$-cell activation to atopic status and expression of allergic disease. Lancet. 363:608-615.

36. Lindgren, U., Lindholm, S., and Sarby, B. 1978. Short-term effects of 1-alpha-hydroxy-vitamin D3 in patients on corticosteroid treatment and in patients with senile osteoporosis. Acta Med. Scand. 204:89-92.

37. Peek, E.J., et al. 2005. Interleukin-10-secreting 'regulatory' T cells induced by glucocorticoids and beta2agonists. Am. J. Respir. Cell Mol. Biol. 33:105-111.

38. Franchimont, D., et al. 1999. Tumor necrosis factor alpha decreases, and interleukin-10 increases, the sensitivity of human monocytes to dexamethasone: potential regulation of the glucocorticoid receptor. J. Clin. Endocrinol. Metab. 84:2834-2839.
39. Torrego, A., et al. 2004. Glucocorticoid receptor isoforms alpha and beta in in vitro cytokineinduced glucocorticoid insensitivity. Am. J. Respir. Crit. Care Med. 170:420-425.

40. Sousa, A.R., Lane, S.J., Cidlowski, J.A., Staynov, D.Z., and Lee, T.H. 2000. Glucocorticoid resistance in asthma is associated with elevated in vivo expression of the glucocorticoid receptor beta-isoform. J. Allergy Clin. Immunol. 105:943-950.

41. Hamid, Q.A., et al. 1999. Increased glucocorticoid receptor beta in airway cells of glucocorticoidinsensitive asthma. Am. J. Respir. Crit. Care Med. 159:1600-1604.

42. Leung, D.Y., et al. 1997. Association of glucocorticoid insensitivity with increased expression of glucocorticoid receptor beta. J. Exp. Med. 186:1567-1574.

43. Schaaf, M.J., and Cidlowski, J.A. 2002. Molecular mechanisms of glucocorticoid action and resistance. J. Steroid Biochem. Mol. Biol. 83:37-48.

44. Chikanza, I.C. 2002. Mechanisms of corticosteroid resistance in rheumatoid arthritis: a putative role for the corticosteroid receptor beta isoform. Ann. N. Y. Acad. Sci. 966:39-48.

45. Akdis, C.A., Blesken, T., Akdis, M., Wuthrich, B., and Blaser, K. 1998. Role of interleukin 10 in specific immunotherapy. J. Clin. Invest. 102:98-106.

46. Burkhart, C., Liu, G.Y., Anderton, S.M., Metzler, B., and Wraith, D.C. 1999. Peptide-induced T cell regulation of experimental autoimmune encephalomyelitis: a role for IL-10. Int. Immunol. 11:1625-1634.

47. Faith, A., et al. 2003. Impaired secretion of interleukin- 4 and interleukin- 13 by allergen-specific $T$ cells correlates with defective nuclear expression of NF-AT2 and jun B: relevance to immunotherapy. Clin. Exp. Allergy. 33:1209-1215.

48. Abramson, M.J., Puy, R.M., and Weiner, J.M. 2003. Allergen immunotherapy for asthma. Cochrane Database Syst. Rev. 2003:CD001186. doi:10.1002/14651858.CD001186

49. Kappos, L., et al. 2000. Induction of a non-encephalitogenic type $2 \mathrm{~T}$ helper-cell autoimmune response in multiple sclerosis after administration of an altered peptide ligand in a placebo-controlled, randomized phase II trial. The Altered Peptide Ligand in Relapsing MS Study Group. Nat. Med. 6:1176-1182.

50. Pedotti, R., et al. 2003. Severe anaphylactic reactions to glutamic acid decarboxylase (GAD) self peptides in NOD mice that spontaneously develop autoimmune type 1 diabetes mellitus. BMC Immunol. 4:2. doi:10.1186/1471-2172-4-2.

51. Cottrez, F., Hurst, S.D., Coffman, R.L., and Groux, H. 2000. T regulatory cells 1 inhibit a Th2-specific response in vivo. J. Immunol. 165:4848-4853.

52. Akbari, O., DeKruyff, R.H., and Umetsu, D.T. 2001. Pulmonary dendritic cells producing IL-10 mediate tolerance induced by respiratory exposure to antigen. Nat. Immunol. 2:725-731.

53. Akbari, O., et al. 2002. Antigen-specific regulatory $\mathrm{T}$ cells develop via the ICOS-ICOS-ligand pathway and inhibit allergen-induced airway hyperreactivity. Nat. Med. 8:1024-1032.

54. Makela, M.J., et al. 2002. The failure of interleukin10-deficient mice to develop airway hyperresponsiveness is overcome by respiratory syncytial virus infection in allergen-sensitized/challenged mice. Am. J. Respir. Crit. Care Med. 165:824-831.

55. Lee, C.G., et al. 2002. Transgenic overexpression of interleukin (IL)-10 in the lung causes mucus metaplasia, tissue inflammation, and airway remodeling via IL-13-dependent and -independent pathways. J. Biol. Chem. 277:35466-35474.

56. Smith, P.J., et al. 2001. Suppression of granulocytemacrophage colony-stimulating factor expression by glucocorticoids involves inhibition of enhancer function by the glucocorticoid receptor binding to composite NF-AT/activator protein-1 elements. J. Immunol. 167:2502-2510. 